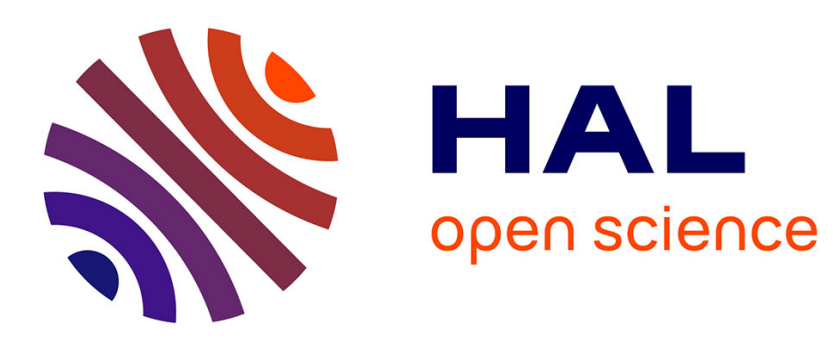

\title{
Political graffiti in May 2018 at Nanterre University: A linguistic ethnographic analysis \\ Camille Debras
}

\section{To cite this version:}

Camille Debras. Political graffiti in May 2018 at Nanterre University: A linguistic ethnographic analysis. Discourse and Society, 2019, 30 (5), pp.441-464. 10.1177/0957926519855788Discourse . hal-03110754

\section{HAL Id: hal-03110754 \\ https://hal.parisnanterre.fr/hal-03110754}

Submitted on 14 Jan 2021

HAL is a multi-disciplinary open access archive for the deposit and dissemination of scientific research documents, whether they are published or not. The documents may come from teaching and research institutions in France or abroad, or from public or private research centers.
L'archive ouverte pluridisciplinaire HAL, est destinée au dépôt et à la diffusion de documents scientifiques de niveau recherche, publiés ou non, émanant des établissements d'enseignement et de recherche français ou étrangers, des laboratoires publics ou privés. 


\title{
Political graffiti in May 2018 at Nanterre University: A linguistic ethnographic analysis
}

\author{
Camille Debras \\ Université Paris Nanterre, France
}

\begin{abstract}
Fifty years after May 68, spring 2018 in France was marked by mass student protest against the Parcoursup/ORE reform of university entry. After a riot police intervention on campus, Nanterre University was blocked and occupied. It was profoundly affected, both as a community and as a physical site. This linguistic ethnographic study proposes a systematic analysis of more than 500 physical interventions (political graffiti, tags and posters) on the campus during that period, to identify the functions of graffiti as political discourse. The graffiti (I) expressed resistance, reclaimed the university's identity and manifested presence on site; (2) established dialogue with local and national authorities and (3) anchored the movement in a larger web of historical references and sites of political resistance. A striking feature was the complex indexicality of the graffiti. Each item was relevant at multiple scales beyond the here and now, anchoring graffiti in larger networks of relations, which endowed them with political power.
\end{abstract}

\section{Keywords}

50th anniversary of May 68, graffiti as political discourse, linguistic ethnography, linguistic landscape, Mai 68, May 1968, political graffiti, student protest in France, Université de Nanterre, university graffiti

\section{Introduction and context}

Nanterre University, officially 'Université Paris Nanterre', also known as 'Paris 10' or simply 'Nanterre', is situated in Nanterre (Hauts-de-Seine department), in the North West of the larger Paris area in France. It was founded in 1964, as an antenna of the

\footnotetext{
Corresponding author:

Camille Debras, Département d'études anglo-américaines, Université Paris Nanterre, UFR LCE, Bureau 230, Casier 28, 200 Avenue de la République, 92000 Nanterre, France.

Email: cdebras@parisnanterre.fr
} 
Sorbonne, so as to open new departments of Literature, Law and Social Sciences when new universities were being created in the 1960s and 1970s. This university played a fundamental role in the May 68 movement in 1968 in France, notably as the birthplace of the 'Mouvement du 22 mars', which was led by faculty union leaders and students, among whom Daniel Cohn Bendit. ${ }^{1}$ May 68 was an anti-authoritarian movement against capitalism, consumerism, American imperialism and De Gaulle's presidency, which led to political and social unrest, massive student demonstrations and general strikes in several professional sectors. This period has durably marked French society, as a pivotal moment when the country opened up to progressist values on the impulse of younger generations.

May 2018 marked the 50th anniversary of May 68, with multiple institutional and popular commemorations. Nanterre University commemorated the anniversary in multiple ways. As part of the University's communication policy, a special label 'Prop'osons $1968-2018$ ' ('Let's propose and dare') ${ }^{2}$ was applied to targeted events in relation with May 68 such as, for instance, the National Congress of English Studies, held at Nanterre University in early June 2018 on the theme 'Revolution(s)', with Dr Angela Davis (who is Dr Honoris Causa of Nanterre University) as a keynote speaker. ${ }^{3}$ The university's official commemoration of May 68 also took the form of a partnership with the Louvre Museum for the street art project 'Sous le street art, le Louvre' ('beneath street art, the Louvre'; with a reference to the famous May 68 slogan 'Sous les pavés, la plage'). ${ }^{4}$ A group of street artists were invited to draw large to monumental frescoes on the campus, with the pedagogical aims of fostering a reflection on the links between art and politics and of inviting the public to rediscover works exposed in the Louvre. The city of Nanterre also commemorated May 68 with the exhibition 'Mai 68 ici et encore' ('May 68 here again/still'), ${ }^{5}$ with pictures exposed on wood panels in multiple places in Nanterre city, for example, at the main exhibition space La Terrasse, in the city centre and on the esplanade leading to the main entrance of the University.

Spring 2018 was also marked by the hasty implementation of Parcoursup/ORE (Orientation et Réussite des Etudiants; Orienting Students for Success), ${ }^{6}$ a reform of university entry modalities, prepared in summer 2017 and voted by the French National Assembly in the fall, after allegedly 'serious' issues with the former system 'Admissions Post Bac'. In the spring of 2017, it was emphasized that candidates had been chosen at random in degrees with more candidates than places, which was rightfully felt as a major injustice. This was a totally unprecedented situation, which broke away with French public universities' long-standing commitment to openness.

A major change in the Parcoursup/ORE law is that applications are examined at the local level: each degree in each university department adjusts the parameters of the national algorithm to create its own recruitment criteria. Even departments that were not 'under pressure' (i.e. the number of 'real' candidates wouldn't in the end outweigh the number of places available in a given degree) were asked to rank applications with this system. More generally, the new system is largely perceived as a way of generalizing the principle of selection to public universities, which had, until now, been reserved to the Grandes Ecoles (mostly of Engineering and Management). ${ }^{7}$

During the academic year 2017-2018, the gradual unveiling of the Parcoursup/ORE reform was paralleled with growing protest in universities across the country, with 
sits-in, general assemblies, demonstrations and the blocking of university premises, in Rennes, Montpellier, Tolbiac (Paris 1), Censier (Paris 3) or Paris 8 (Vincennes - SeineSaint Denis) and Nanterre Universities among others. In early April 2018, tensions were high at Nanterre University; on the night of 8 April, the University's presidential team received a communiqué from an anonymous group with multiple political revindications, who stated a planned action to occupy the University and cause degradations there on Monday, 9 April. On the morning of Monday 9th, a small group of activists (about 30) were indeed present on campus, and the University Presidential team decided to send the riot police to stop them. The small group of activists went to the roof of building E with political placards and then quickly dispersed. The riot police then turned to a pacific group of students who were holding a meeting in an amphitheatre and took them out one by one. The intervention was disastrous, with the riot police largely outnumbering the students and molesting pacific students under the eyes of helpless faculty members. Three students were placed in police custody for fighting back the riot police. No one was badly hurt, but the experience was traumatic for the university community and caused massive indignation, incomprehension and anger. Instead of breaking up the student protest, the riot police intervention fostered it. A group of students started a roundthe-clock occupation of building E, which is one of the oldest buildings on campus and the closest to the University's main entrance, while a team of mobilized students blocked the entry of all the other buildings on campus. They protested against the riot police intervention by blocking the organization of final exams and demanded, among other things, charges to be abandoned against the three accused students and the withdrawal of the Parcoursup/ORE reform.

Nanterre University was not an isolated case: all student mobilizations against Parcoursup/ORE across the country were severely put down by riot police interventions. Universities were not the only site of political and social unrest: on the ZAD (Zone à défendre; Area to defend) at Notre-Dame-des-Landes near Nantes, where a project of building a huge airport had long been discussed and finally abandoned in 2018, the antiairport activists who had long occupied the area so as to defend it $^{8}$ were violently expulsed by the riot police during several weeks in the spring. ${ }^{9}$ At the same time, the national train company (SNCF) went on a go-slow strike against a reform of the train workers' status which lasted 3 months from 3 April to 28 June. ${ }^{10}$

As for Nanterre University, teaching and exams were virtually paralysed for 3 months, from early April to late June. The mobilized students were soon joined by mobilized personnel and faculty. ${ }^{11}$ They held multiple meetings and repeatedly demanded to be heard by the University's presidential team. Their main claims were to repeal Parcoursup/ORE, to free the three students in police custody and abandon charges against them, the automatic validation of final exams for mobilized students to focus on the protest movement against Parcoursup/ORE and the resignation of University President Jean-François Balaudé. Alternative classes and workshops on the future of French universities were organized with a whole week of participative workshops, 'Les Etats généraux de l'Université' from 4 to 8 June 2018. ${ }^{12}$ Tensions remained high, because the mobilized group were exasperated at the Presidential team's silence and also because a large proportion of the Nanterre University Community (33,000 students, 2000 faculty, 700 personnel) were against the mobilization, even if mobilization meetings counted up to 1600 participants. ${ }^{13}$ 
The Presidential team attempted to evade the mobilization by delocalizing final exams, but this failed since mobilized students came to block them. ${ }^{14}$ In the end, finals were held online via the online platform, and the movement gradually faded away with the implementation of Parcoursup/ORE, hesitant mobilization on the part of high school students and possibly the end of the academic year.

The mobilized group resented the refusal of dialogue and negotiation from the University Presidential team, ${ }^{15}$ whose silence was interpreted as buying time: it would be hard to repeal Parcoursup/ORE once the algorithm had started to assign places to prospective students. They also suffered from being made invisible by the Presidential team and the national media: the University's President took a consensual stance in the media, refusing the notion of 'selection' but highlighting the positive aspects of the reform. ${ }^{16}$ The media presented the movement as a lesser replica of May $68{ }^{17}$ and focused attention on some faculty's proposition to give the highest grade of 20/20 to all papers at the final exams as a 'political grade' to relieve mobilized students from the stress of revising. ${ }^{18}$ This idea was caricatured by French President Emmanuel Macron who stated in a TV interview that degrees 'wouldn't be given out like chocolates' ('il n'y aura pas d'examens en chocolat'). ${ }^{19}$

The May 68 commemorations, the riot police intervention, the mobilization against the Parcoursup/ORE law and the partial occupation of the campus have, at least temporarily in the spring of 2018, profoundly affected Nanterre University, both as a community and as a physical site. The University premises were seized as a locus for action by various social and political actors. Political meetings, the riot police intervention, the street art commemoration project, the occupation of the premises, the political graffiti and posters which massively covered the campus, inside and outside, in a long-standing tradition of student activism - all profoundly affected the University's linguistic landscape (Barni and Bagna, 2009) during that period. In this article, I propose a linguistic ethnographic study of Nanterre University's modified linguistic landscape during that period, based on the systematic multimodal analysis of more than 500 physical interventions on the University site: not only political graffiti but also tags and posters. Graffiti is usually perceived as physical degradation, especially on public university campuses, where authorities chronically lack budget and will all the more struggle to fix the damage done. Nevertheless, these physical interventions voice political stances and map power relations that are not expressed anywhere else, and for that reason, deserve documentation and analysis. When I came back on campus after the summer break on 3 September 2018, virtually all the political graffiti linked with the mobilization had carefully been cleaned, repainted and erased, while older tagging had been left untouched. Beyond the necessity of maintaining clean and operational facilities on campus, this careful yet selective makeover is a first indication of the crucial political role played by graffiti.

More specifically, I investigate the following research questions: how do the physical interventions on the Nanterre University campus (1) manifest freedom and resistance to various forms of oppression, (2) enable a dialogue between mobilized groups and authorities and (3) make visible political groups that feel otherwise marginalized?

\section{Graffiti as micro-level political discourse}

In its most basic definition, graffiti is a visual inscription, written or pictorial, on a publicly accessible surface (Blume, 1985; Hanauer, 2011; Kostka, 1974). Graffiti is a long-standing 
human practice which has aroused scholarly interest for a long time (Tanzer, 1939). Even in today's digital era, which provides avenues for people to express themselves freely, anonymously and without limits on social networks, people persist in writing on walls (Matthews et al., 2012). This suggests that graffiti keeps fulfilling dedicated social functions. As Abel and Buckley (1977) remark, graffiti is usually characterized by discursive uninihibitedness:

graffiti is a form of communication that is both personal and free of the everyday social strains [...]. As such, these sometimes crude inscriptions offer some intriguing insights into the people who author them and into the society in which these people belong. (p. 3)

The political functions of graffiti have long been identified. For Pietrosanti (2010), 'political groups use graffiti as a communication tool. Major themes for political graffiti are associated with labor conditions, freedom, political power, unemployment, religious thought, and civil rights' (p. 2). For Hanauer (2011),

graffiti is an act of public literacy that brings marginalized messages within the wider sphere of public discourse. [...] It is a genre that is used by marginalized social groups who want their positions to be heard (Hanauer 1998, 2004; Peteet, 1996). In this sense, graffiti can be seen as a form of political discourse competing with political statements from other discourses. What is interesting about graffiti writing is that it is a local action, performed at particular sites and as such is a form of micro-level political discourse in which every day (and usually unnamed) people publically present their political understandings. The analysis of political graffiti may allow the performance of political discourse to be observed on the micro as well as the macro levels.

Following Adams and Winter (1997), graffiti is different from tagging. They have similarities, in that they are both usually written in spray paint and can be found in the same or similar places; they can be read with difficulty by people outside a given subculture and can both be interactional. Tagging

consists of the 'tag' or nickname of the writer often accompanied by the name of the group or 'crew' the writer belongs to. Tagging crew members form a loosely knit group of individuals from various neighbourhoods and socioeconomic groups whose main purpose for coming together is to tag. The more artistically talented members also paint large murals. [...] The tagger's goal is to write his tag in the most difficult places, the most times and in the most artistic way to get recognition from his crew, other crews and the community at large. (Adams and Winter, 1997)

If tagging can be considered political in the appropriation of public space with signatures, graffiti can constitute explicitly political discourse and stances with symbols and messages.

Multiple studies have documented the use of graffiti in universities around the world. Several studies focus on university latrinalia (writing on toilet walls), highlighting gender differences (Cole, 1991; Green, 2003; Otta, 1993), social and political issues (Nwoye, 1993; Obeng, 2000; Schreer and Strichartz, 1997) as well as taboos (Farnia, 2014). As Hanauer (2011) further notes, 
the analysis of graffiti and other forms of public literacy in areas of contestation offers a methodological approach for exploring micro-politics and addresses what Wodak (2006) has identified as a gap in current research - ethnographic sociolinguistic research of political discourse.

\section{A linguistic ethnographic approach; data and method}

The methodological framework adopted here is anchored in linguistic ethnography (Show et al., 2015): the study is topic-oriented, brings together multiple sources of data and is proposed by a participant observer. As an Associate Professor in English Studies at Nanterre University and a city-dweller of Nanterre, I have secondhand but also firsthand knowledge of the data. I have not participated in the mobilization per se, but I have largely discussed the issues at stake in department meetings and with those of my students and colleagues who were mobilized, or who weren't. So as to stay informed of the latest developments, I attended meetings of the mobilized personnel, faculty and students. I carefully read all the email communiqués sent by the University's presidential team as well as by the mobilized group, and regularly followed the official University's and the mobilized students' Facebook and Twitter accounts. Like many members of my university, I was shocked and angered by the riot police intervention on campus. Like many, I spontaneously documented some of the posters and graffiti by taking pictures of the campus and the occupied buildings with a feeling that this period was an important landmark in our University's history.

On the morning of 4 June 2018, I set out for a tour of the campus and took 230 photographs of physical interventions with my smartphone. I photographed all interventions I could see on outside walls. I then entered occupied building $\mathrm{E}$ and photographed physical interventions on the ground floor, first, second and third floors and in the staircases. I did not document floors 4 and 5 in building E, or the occupation and/or degradations in building D next door, because I did not feel comfortable doing so. A few days later, I took 7 additional photographs of the outside, and a mobilized student of mine sent me 7 additional pictures of the outside and the inside of building $\mathrm{E}$, taken in May with her camera.

In July 2018, when exams were over and the occupation had ceased, I went on to analyse the data. I undertook a systematic description and qualitative analysis of each physical intervention, documenting its location (what building; inside or outside); the object of the intervention (wall, ceiling, other intervention, etc.); the kind of intervention (political graffiti, tag, etc.), its putative author (university officials, mobilized team, etc.); its semiotic mode (icon, discourse or both), its scale (large, medium, small or a combination), its language (e.g. French, English); its discourse content.

The whole corpus for this study includes 511 items.

409 political graffiti (there were far more but many were undecipherable),

35 tags (there are actually far more on campus),

15 pieces from the Louvre/Nanterre University Street art project,

2 large placards of Official University communication, 
10 large reproductions of photographs in black and white,

12 sleeping bags hanging from windows of the first floor of building $\mathrm{E}$.

In total, 165 items were found outside, 332 were collected inside building E, 14 were at the limit between the inside and the outside, for example, posters on windows facing outside, and sleeping bags hanging at open windows, as blatant metonymies of building E's occupation. The article does not aim at exhaustive analysis but rather identifies the main functions fulfilled by graffiti as political discourse.

In the following sections, I analyse the collected items in light of the research questions formulated in the introduction. The 'Setting the scene: remodelling the university's main entrance' section explains how the university's main entrance was remodelled to re-stage the founding traumatic event of the riot police intervention that triggered the mobilization and partial occupation of the premises. Section 'Expressions of freedom: resist oppression, reclaim identity, manifest presence' shows the diverse ways in which the graffiti express freedom, through resistance inspired from anarchist and autonomous movements, by reclaiming the university's identity and by manifesting presence on site. The 'Enable dialogue: mobilized groups talk (back) to authorities' section shows how the graffiti were used as a means to establish a dialogue with local and national authorities. The 'Stating legitimacy in time: historical and intellectual anchoring' and 'Spatial anchoring: indexicalities and converging fights' sections show how the graffiti sought legitimization of the mobilization both in time and space by anchoring the movement in a larger web of historical references and sites of political resistance.

\section{Setting the scene: remodelling the university's main entrance}

Physical interventions at the campus' main entrance, which faces building E, proposed a re-staging of the riot police's intervention of 9 April 2018. Outside, on the esplanade leading to the main entrance, the campus map was covered with a large reproduction of a black-and-white photograph of a riot police squad, welcoming the visitor in its stead (Figure 1). Three large reproductions of black-and-white photographs were glued on a visible wall of building E. A testimonial picture of the riot police intervention which occurred inside that very building on 9 April 2018 was presented first, as a founding event. The second picture represented a demonstrator, literally fighting back by sending a Molotov cocktail. The third picture showed a scene of riot police violence, with riot police beating someone on the ground on a street. On the esplanade, the wood panels of the Nanterre city's exhibition 'Mai 68 ici et encore' were stripped of their original posters. Only the original title of the exhibition remained, and three large reproductions of black-and-white photographs were posted instead. These pictures documented the events of 9 April as one could have seen them from the esplanade (Figure 1). They showed the activist group on the roof of building E, with the riot police ready to intervene in the foreground, as an archive of that founding event, immediately letting visitors experience what they would have seen from the esplanade, there and then. The placard 'Nanterre sur 


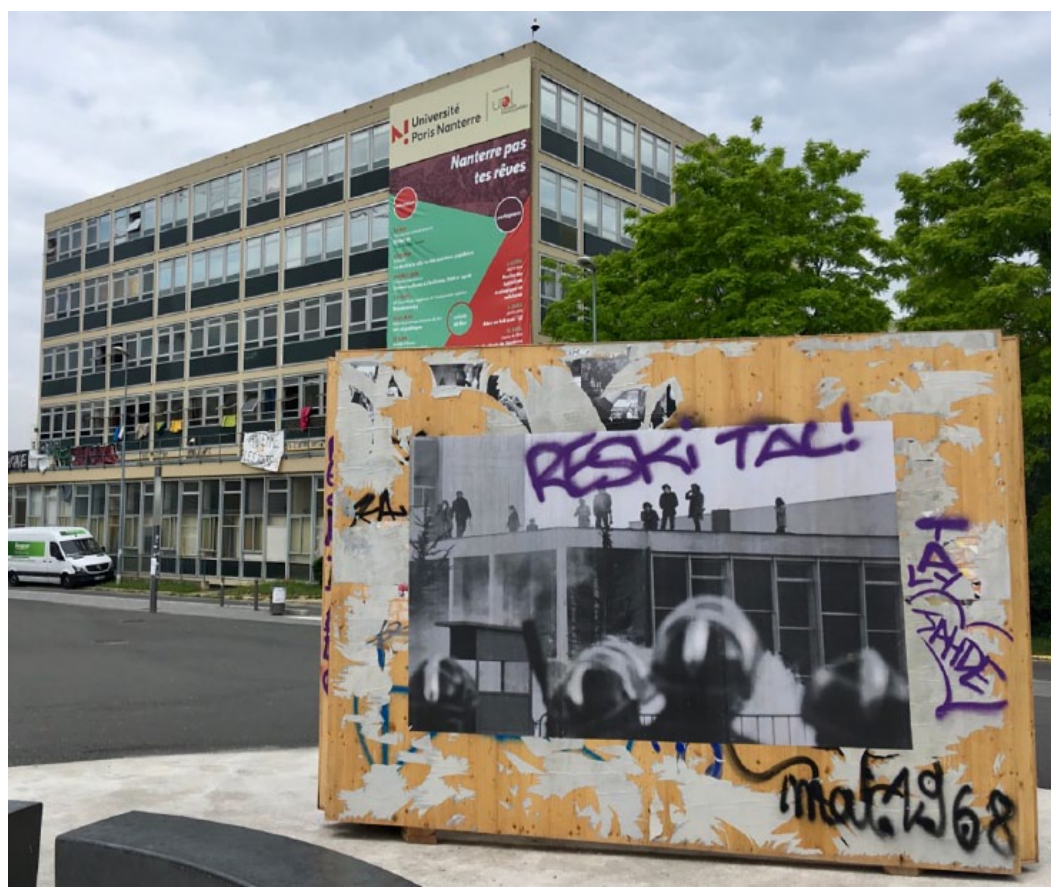

Figure I. Re-staging the riot police intervention.

les toits' ('Nanterre on the roofs'), visible in one of the pictures, was actually still hanging from the roof on 4 June 2018 (see Figure 1), as a sign of the on-going occupation of the premises.

The University's official large communication panel which faces the visitor on building E, at the main entrance, was tagged. The University's May 68 commemoration slogan, 'Prop'Osons, 1968-2018' ('Let's propose and dare') was subverted by adding the complement 'des flics sur la fac', changing the meaning to 'let's dare to propose cops on the campus'. Another tag, 'Nanterre contre les flics' ('Nanterre against cops'), claimed an alternative identity for 'Nanterre', different from the University's official communication, equating with a university community that, precisely, opposed the police intervention.

\section{Expressions of freedom: resist oppression, reclaim identity, manifest presence}

A striking theme in the data was to expose police violence, reject it and fight it back. Graffiti and posters expressing resistance to (police) authority took multiple forms, many of which are traditional symbols of extreme-left, anarchist and/or autonomous movements. These movements inspired and shaped up at least part of the occupation, which included members of these movements who were not necessarily students of the 
university. Recurrent symbols in the graffiti, inside and outside, were the anarchist A (an A framed in a circle, used either in isolation or in the spelling of slogans), as well as the autonomous squatters' sign (resembling a circled $\mathrm{N}$ with a pointed arrow, with extra resonance with the initial $\mathrm{N}$ in 'Nanterre'). A third recurrent symbol is the 'mort aux vaches' sign (an anti-authoritarian insult to the police from the $1960 \mathrm{~s}$, literally calling the police 'cows' and wishing them dead) consisting of three dots disposed in an equilateral triangle; it was either used alone or accompanying slogans. Another of these frequently used coded graffiti was 'ACAB' or ' 1312 '. ACAB is a famous anti-police acronym standing for 'All Cops Are Bastards' which became popular during the miners' strikes in 19841985 in Britain. The acronym has also been taken up by anti-capitalist activists with the meaning 'All capitalists are bastards'. ' 1312 ' is a code standing for 'ACAB', with each number standing for the letter's place in the alphabet $(1=\mathrm{A}, 3=\mathrm{C}, 1=\mathrm{A}, 2=\mathrm{B})$. Interestingly, variations 'ABAC' and ' 1213 ' were also found recurrently: $\mathrm{ABAC}$ has no conventionalized meaning in extreme-left movements but could refer to the rewriting 'All Balaudé Are Cops' found in some campus graffiti ('Balaudé' being the University President's last name), equating the University's President with the police after the traumatic riot police intervention.

With graffiti and posters, appropriation of the university was performed both concretely and discursively, either through the expression of reclaimed identity: 'la fac c'est nous, ok?' ('we are the university, ok?') or possession: 'la fac est à nous' ('the uni is ours'), 'la fac est à toi et moi' ('the uni is yours and mine'). Nanterre was recurrently referred to with the alternative name NTR (a shortened version in which only the consonants appear) in the graffiti. The emergence of this alternative name symbolized a fractured university community, within which the mobilized group felt a need to reclaim and redefine an alternative identity for themselves. NTR is also used in the mobilized students' Twitter and Facebook accounts. In the Twitter account, NTR_VNR, VNR stands for 'véner(e)' a verlan (slang reverse form) of 'énervé', ('angry'). ${ }^{20}$ 'Nanterre Vénere' was also the name of the university's mobilized group on Facebook, whose alias is @ NTR.VS.VIDAL, ${ }^{21}$ which explicitly opposes Nanterre to Frédérique Vidal, the French Minister for Higher Education, Research and Innovation in charge of the Parcoursup/ ORE reform.

Faced with the University presidential team's silence and the mainstream media's caricatural presentation of the movement, the mobilized group felt largely invisibilized. As a response, graffiti, posters and 24/7 occupation were an obvious and concrete way of manifesting presence at a local level. Many graffiti focus on the themes of presence and visibility: 'on est là', 'on est là hein', 'on sera là hein' ('we're here', 'we're here, you know', 'we'll be here you know') are used recurrently. The colourful sleeping bags hanging from the windows play a similar semiotic function of metonymically manifesting presence. Appropriation of the university's site is done literally, by occupying the premises. With a marker, in small scale, an occupant of building E has written the following on the wall, next to a door with a door code: 'le prochain qui rentre peut-il mettre les affaires ci-dessous dans cette salle? Merci:) PS: il y a mon sac de couchage + mon tapis de sol dans cette salle et je n'ai pas le code' ('Can the next person who goes in here put this stuff in the room ? Thanks:) PS: There's my sleeping bag and mat in this room and I don't have the code'). This small graffiti, apparently trivial and practical in its content, is 


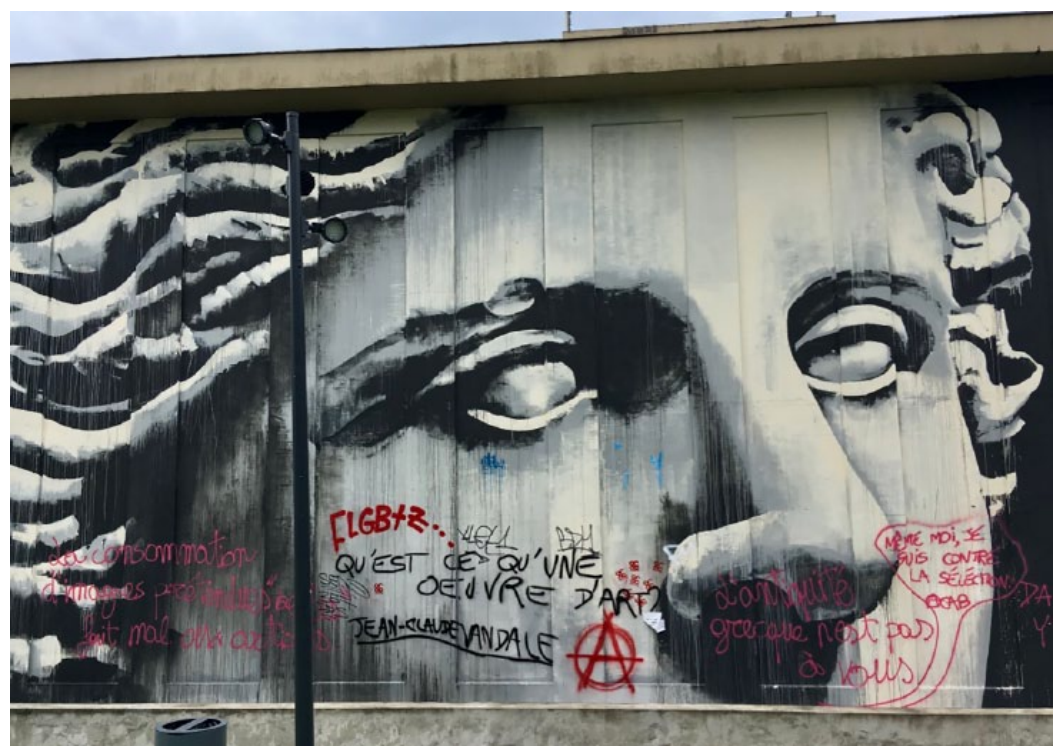

Figure 2. Louvre/Nanterre street art project fresco opposite Humanities building, with critical graffiti.

no less political than slogans in large letters: by indexing the larger context, this written piece of discourse leaves, at least temporarily, a lasting trace of the time and place of the occupation.

\section{Enable dialogue: mobilized groups talk (back) to authorities}

The mobilized group (students, personnel and faculty), repeatedly explained how they suffered from a lack of dialogue with the University's presidential team in multiple online communiqués. ${ }^{22}$ On campus, the visitor was reminded of this absence of dialogue by the graffiti 'Saroumane descends' ('Saruman come down', this humorous reference from popular culture equating the President with the evil and powerful sorcerer from the Lord of the Rings, remote in his tower) on Building B, a tall building where the presidential team's offices are located. Graffiti were used to establish a form of dialogue between the presidency and the mobilized group. Several of the works from the Louvre/Nanterre street art project were covered with graffiti or posters, the mobilized group thereby replying to the presidency with like means. One large fresco facing Humanities and Classics building L representing a close up on the face of an antique statue bears the large slogan 'la beauté sauvera le monde' ('beauty will save the world'). The fresco was covered in critical graffiti (Figure 2). 'La consommation d'images prétendues belles fait mal aux artistes' ('the consumption of supposedly beautiful images hurts artists') mimicked the format of the fresco's naïve slogan (declarative statement proposing a general truth) in a fiercely critical way. The pun 'dans saboter y'a beauté' relied on phonetic proximity 
between 'sabotaging' ('saboteur') and 'beauty' ('beauté') in French. It alluded to the degradations operated during the occupation of the campus, suggesting that the supposed beauty of the fresco was another form of visual sabotage. A mock-high-brow quote: 'qu'est-ce qu'une œuvre d'art?' ('what's a work of art?') was signed 'Jean-Claude Vandal', a porte-manteau name merging the famous action movie actor's name J.-C. Van Damme and 'vandal', rejecting the fresco as mock-artistic practice observed by a mockart critic. 'L'antiquité grecque n'est pas à vous' ('Greek antiquity is not yours') rekindled the dialectic of appropriation, with the graffiti contesting official discourses on, and definitions of, art, history and art history, and knowledge of Antiquity. This graffiti had special resonance since the University president's research field is antique philosophy. Among other inscriptions like tags and anarchist symbols, the statue was made to speak and to side with the mobilized group with a graffiti in the form of a comics bubble: 'même moi je suis contre la sélection, ACAB' ('even I am against selection, ACAB').

The dialogue between the presidency and the mobilized group became even more complex in other loci of the Louvre/Nanterre street art project. Posters of antique statues and a reproduction of Delacroix's 'La Liberté guidant le peuple' (a famous 19th-century allegorical painting representing the French 1789 revolution ${ }^{23}$ ), were glued on a visible wall of building D, over an older graffiti of the word 'liberté' ('freedom'). A closer analysis revealed at least 5 layers of intervention: signature tags, tearing of the posters, graffiti and gluing of new posters by the mobilized team. Interestingly, each intervention was made in a way that the superposition could be seen, covering only partly what was underneath, thereby unveiling the multiple layers or turns in this dialogue. The comics-bubble graffiti was a recurrent strategy for mobilized graffiti to endow statues or characters on paintings from the Louvre with speech. The statues' supplicating poses were humorously subverted with attributed speech, such as 'je n'ai pas été sélectionné' ('I wasn't selected' - implicitly by the Parcoursup algorithm), 'je veux aller en cours' ('I want to go to class'), with the caption 'l'étudiant captif.ve' ('the captive student' in gender-neutral writing) below.

Dialogue with authorities was also achieved through discursive polyphony, by more or less direct quotes and allusions to public statements. Torn and tagged glued posters reproducing Louvre paintings were accompanied by the large graffiti 'Violence, Drogue, Sexe même ...' ('Violence, Drugs, Sex even ...') on building E (Figure 3). This was actually a quote by Tolbiac University President Georges Haddad, from a TV interview. ${ }^{24}$ Georges Haddad had explained how the occupation had become excessive and uncontrollable, but many of his accusations were rejected as calumnious by the occupying team at Tolbiac (Paris 1). Critical parodic videos had been subsequently filmed inside Tolbiac and broadcast on social networks in the following days, showing that the occupation of Tolbiac was actually well organized and included pacific meetings and debates. ${ }^{25}$ Tolbiac University was violently emptied by the riot police soon after, on 20 April. ${ }^{26}$

The graffiti 'Balaudé arrête de regretter et commence à démissionner' ('Balaudé stop regretting and start quitting' on the Maison des Etudiants (House of students' Associations and activities), directly addressed Nanterre University's President. This apostrophe took up the presidency's communiqué posted on the University's website on 11 April 2018, in which Pr. Balaudé explained that he did not regret the riot police intervention but regretted its consequences. ${ }^{27}$ The blunt imperative mode used in the graffiti expressed 


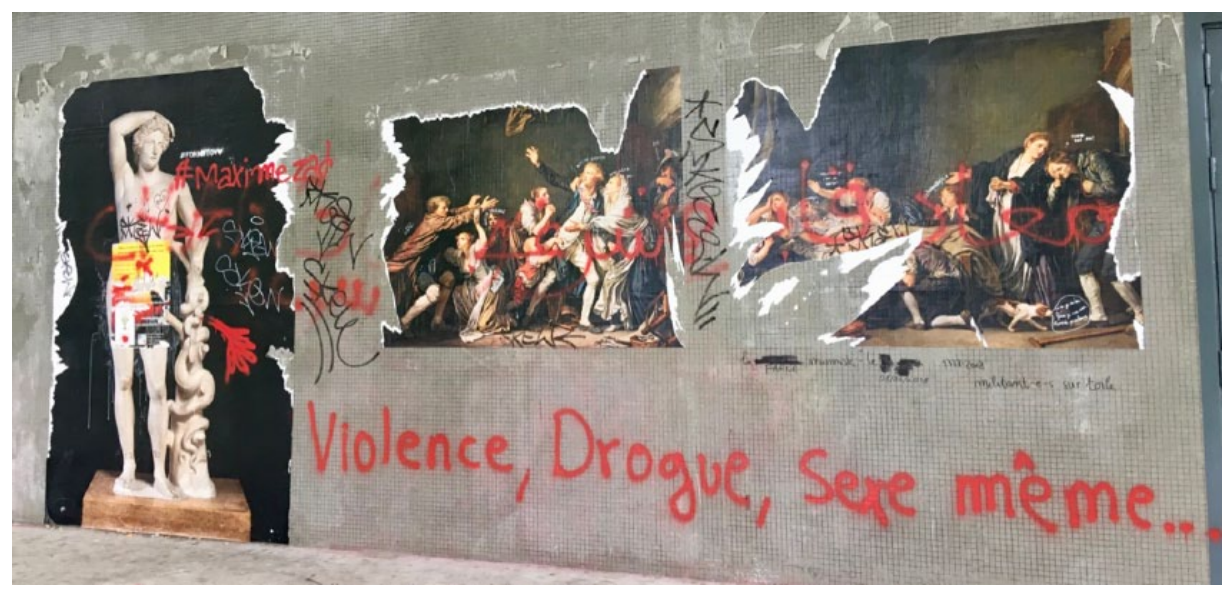

Figure 3. Torn Louvre/Nanterre street art project posters on an outside wall with graffiti.

exasperation, after a declaration perceived as fairly confused by some. The University President's name was used in a number of puns like 'balaudégradation' or 'balaudémission' (portemanteau words including the French words for 'degradation' and 'resignation') which, beyond their humorous function, constituted a form of address to, or request from, the presidential team.

The Minister of Education, Jean-Michel Blanquer; the Minister of Higher Education, Frédérique Vidal; and the French President Emmanuel Macron (who ironically has been a Nanterre student) were also mentioned; they were addressed vehemently, with such messages as 'VIDAL donne ta DEM' ('VIDAL hand in your notice') and attributed discourse: 'Vous n'avez pas de futur! Macron feat. Vidal' ('You have no future! Macron featuring Vidal', in a parody of a hit song title with Mme Vidal as a guest) or just derogatory assessments such as 'MEUH VIDAL-BLANQUER' ('MOO VIDAL-BLANQUER', the two names being coupled in association with a cow's mooing). The University President's name is associated with Macron's name in a large graffiti on a visible outside wall: 'Macron Balaudé tous les chefs / Prison d'or / gêolier tu es prisonnier aussi' ('Macron Balaudé all leaders / Golden prison / prison ward you are imprisoned too'); this poetic writing style, suggesting a Hegelian reversal of power relations, is written in gold spray paint on a black wall. 'MACRON M'A TUER' ('MACRON KILLED ME') in the main mobilization room on the ground floor of building $\mathrm{E}$ is a parody of an element of a famous murder case known as the Omar Raddad case from the early 1990s (with an intentional grammar mistake in the French past participle). ${ }^{28}$

Macron's statement 'il n'y aura pas d'examens en chocolats' from his TV interview on 12 April 2018 was taken up and transformed in multiple ways. At the bottom of a poster in the mobilization room, after a list of claims, one could read, 'LES NEGOCIATIONS AU CHOCO, C'EST DE LA POUDRE DE PERLINPINPIN' ('CHOCOLATE NEGOCIATIONS ARE A CHARLATAN'S REMEDY'). This slogan conflated of Macron's 'chocolate' quote with another one from the last debate in the presidential election that opposed him to far-right candidate Marine Le Pen about a year 


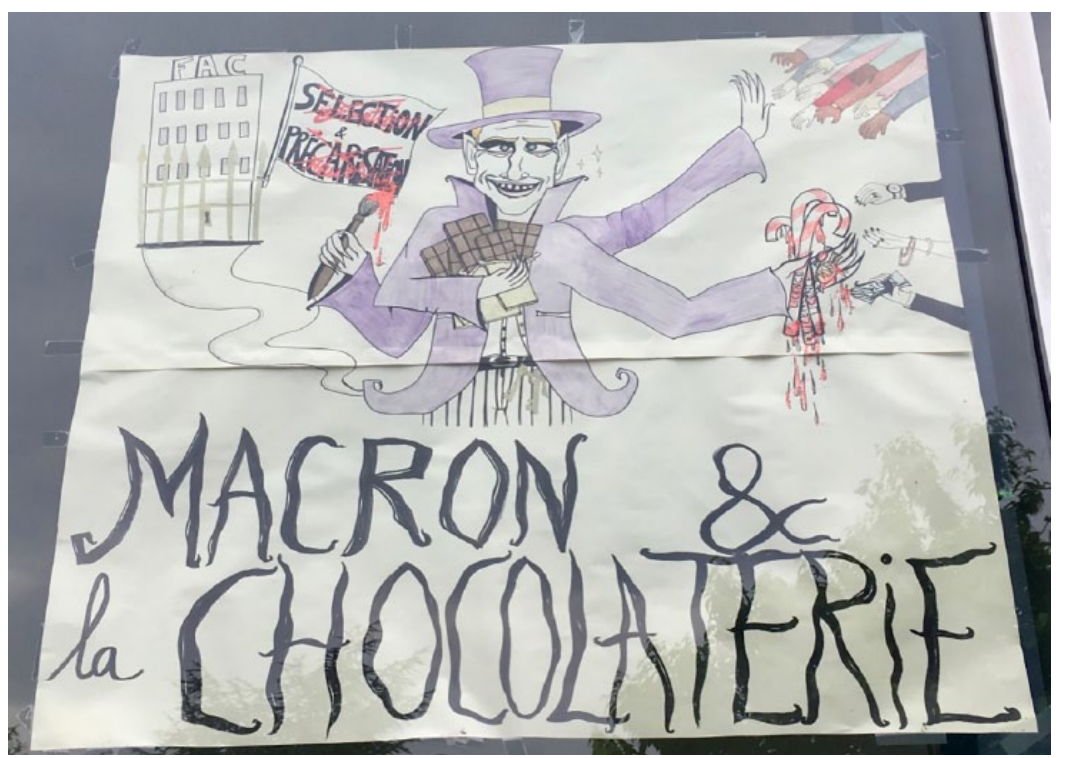

Figure 4. Caricature drawing facing outside, ground floor, building E.

before on 3 May 2017, during which he had famously discarded her programme as 'poudre de perlimpinpin', that is, a charlatan's remedy. The poster thereby turned Macron's own discourse against him, discarding the President's own propositions in turn. The graffiti 'j'ai mangé trop de chocolat je me sens balaudé' ('I ate too much chocolate I feel balaudéed/bloated'), with a pun on the quasi homophony between 'Balaudé' and 'balonné' ('bloated'), rejects both national and local university policies as indigestible, intertwining Macron's 'chocolate' quote and Balaudé's name. A caricature drawing of Macron titled 'Macron et la Chocolaterie' ('Macron and the Chocolate Factory') was posted on a window on the ground floor of building E (Figure 4). Macron was represented as the main character from the film Charlie and the Chocolate Factory, ${ }^{29}$ giving out chocolates and candy in the hands of White, rich students, while refusing to put anything in the hands of middle- or lower-class, poorer students of various skin colours.

These examples show how the graffiti on campus fulfil a major political function of establishing dialogue with, but also criticism of, elected representatives, at the local as well as at the national level.

\section{Stating legitimacy in time: historical and intellectual anchoring}

Graffiti were used not only to manifest presence but also to legitimize the movement and the occupation. This was done by inscribing the movement in a larger web of historical events and figures. May 68 was a recurrent reference. Student protests were severely criticized and repressed in May 68; in the spring of 2018, while student protests received 
a similar treatment, archive images of student graffiti or rebellion from May 68 were constantly put forward in official commemorations. On the Nanterre Campus, a large graffiti 'ce tag sera légitime dans 50 ans' ('this tag will be legitimate in 50 years') barring one of the monumental frescos from the Louvre/Nanterre street art project on a visible wall highlighted this paradox at 50 years' distance. It launched a dialectical reflection on the (il)legitimacy of wall inscriptions and student protest and the historicization of events. This tag was erased during the summer cleaning, but the official Louvre street art fresco was left intact. Another obvious reference to May 68 is the appropriation of a famous slogan from that period, 'sous les pavés, la plage' ('under the cobblestone, the beach') $)^{30}$ by all sides. One variant of the slogan was used in official commemorations as part of the Louvre/Nanterre street art project's name 'Sous le street art, le Louvre' ('under street art, the Louvre'). It was also appropriated in the Nanterre graffiti, as in 'sous les k-ways, le malox' ('under the waterproof coats, malox' ${ }^{31}$ ). The phonetic proximity of 'sous les pavés' and 'sous les k-ways' in French highlights the link made between the May 68 and the Spring 2018 protests by comparing the protesters' equipment for demonstrations at 50 years' distance. In 1968, they threw cobbles at the police, in 2018 mobilized students in demonstrations wear waterproof coats and swimming pool glasses and use Maalox and saline solution to protect themselves and relieve their eyes and skin from the teargas abundantly projected on them by the police.

Another legitimization strategy was the constant reference to intellectual and historical figures. These were concentrated inside occupied building E. In the large hall on the ground floor, one could read among other graffiti 'Freud from Desire', 'Lacan sur les mûr.e.s', 'aux enfants de Montmartre la Victoire ou le tombeau LM', an Amphitheatre renamed 'Amphi Martha P Johnson', 'DECONSTRUISEZ-VOUS', and in the staircases the slogan 'Penser, casser', a reference to George Perec, and a text on a painting by Paul Klee leading to a reflection on history and progress, written by Walter Benjamin.

'Freud from desire' (Figure 5) is a pun on the song title 'Freed from desire' by Italian singer Gala, a 1996 pop hit single. This song was often played during the occupation of the campus and appropriated by the movement as an anti-capitalist, antiliberal hymn, because of its lyrics. ${ }^{32}$ The original title of the song was also recurrently tagged on the walls, indexing the occupation by inscribing memorable moments on the occupied space. The pun 'Freud from desire' created a variety of simultaneous meanings: an appropriation of psychoanalytical theory so as to pinpoint mechanisms of alienation, giving more depth to the pop song hymn, but also setting young generations free from institutional references by making fun of a canonical author.

'Lacan sur les mûr.e.s' (Figure 5) was a pun proposing several meanings since 'mur' ('wall'), 'mûr' ('mature or ripe') and 'mûre' ('blackberry') are homophones in French: 'Lacan on the walls/ Lacan on the blackberries / Lacan on the mature ones', and including the feminine and plural in gender-neutral writing with 'e.s'. This graffiti metadiscursively alluded to Lacanian psychoanalysis, in which homophones and double meanings play a central role. 'Lacan on the wall' expressed reflexiveness of the graffiti itself; the other possible meanings are opaquer. The fruit image brings in light-heartedness, the idea of maturity could allude to the mobilization itself or the idea of ripeness suggests that the time has come for action. 'Aux enfants de Montmartre la victoire ou le tombeau LM' ('victory or the grave to the children of Montmartre', Figure 5) is a quote by Louise 


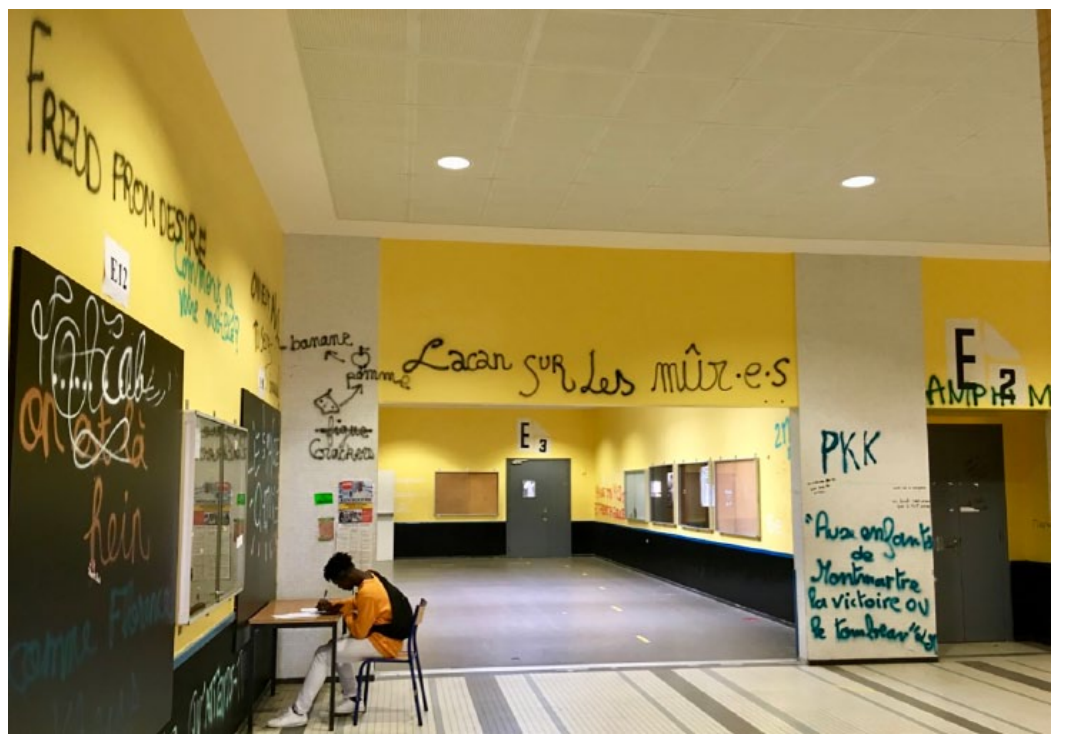

Figure 5. Graffiti, main hall, ground floor, building $\mathrm{E}$.

Michel (referred to as LM in the graffiti), who was an anarchist, a feminist and one of the most famous figures of the Paris Commune, a radical socialist and revolutionary government that ruled Paris from March to May 1871. This reference presented the student protest as a revolutionary movement and a direct offspring of the Paris Commune, also suggesting that women play decisive roles in political revolutions.

The graffiti ‘Amphi Martha P Johnson' renamed amphitheatre E2 on the ground floor of building E (Figure 6), reminding the viewer that renaming is a fundamentally political act. ${ }^{33}$ This renaming also had a local political meaning: the Nanterre campus buildings had historically been identified by letters until 2017 when they were renamed after famous intellectuals, as part of a makeover of the university's communication and identity. ${ }^{34}$ Renaming the amphitheatre in the occupied building was hence an alternative response of protestation against institutional decisions. The choice of transgender drag queen and lesbian, gay, bisexual and transgender (LGBT) activist Martha P Johnson's name inscribed the students' movement in the wake of 1960 s activism, ${ }^{35}$ but also in a largerweb ofalternativerevindications. 'DECONSTRUISEZ-VOUS'('DECONSTRUCT YOURSELVES', Figure 6) is a reference to Derrida's 1960s concept of deconstruction, an analytical method aiming to reveal the implicit ideologies of dominant or mainstream discourses and texts. The graffiti invited to apply this post-modern method to individuals' identities, reminding the visitor that political issues are also constructed at the microlevel of individual identities.

In a staircase leading up to the first floor in occupied building E, 'penser, casser' ('think, break') was a pun on the title of Penser/Classer, ('think, classify') a collection of essays by George Perec published posthumously in 1985, on the question of classifying and ordering books in his library as well as objects and concepts. The title was 


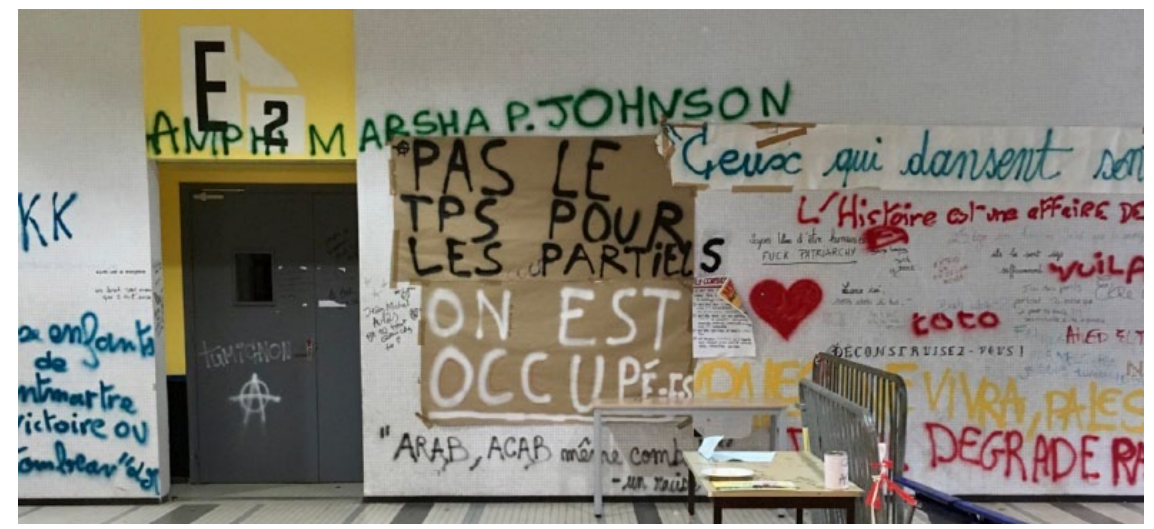

Figure 6. Graffiti and posters, main hall, ground floor, building E.

revisited and modified based on the paronomasis (sound similarity) between 'classer' ('classify') and 'casser' ('break'). This slogan can be understood as programmatic: once you start thinking about the situation, the only conclusion you can come to is to destroy sites of institutionalized political oppression. It can also be read as a legitimization of the degradations imposed on the university's facilities during the mobilization, framed as the result of political reflection.

In another staircase, a paragraph by philosopher Walter Benjamin was copied out on a wall with a marker; this ekphrasis (minute description) of a small watercolour painting by Paul Klee titled 'Angelus novus' which belonged to Benjamin, is an excerpt from Benjamin's 1940 essay 'Theses on the Philosophy of History' that proposes a reflection on the notions of history and progress. ${ }^{36}$ With this graffiti, the university as a physical site became a locus of interdisciplinary thought, with a quote that merged political, historical and aesthetic analysis. It could be read as a response to the Louvre/Nanterre Street Art project: Benjamin's quote displays mastery of canonical references, with analyses of the relation between art and politics that are more referenced, abstract and complex than what is proposed by the pedagogical Louvre/Nanterre Street Art project.

Intellectual and historical references were also found on the outside walls, such as 'Qui a du fer, a du pain' ('the one who has got iron, has got bread'), on the Maison de l'Étudiant (Figure 8) and 'on pense donc on ne vous suit plus' ('we think therefore we won't follow you anymore', Figure 7) on building C.

'Qui a du fer, a du pain' is a famous quote by August Blanqui, a 19th-century revolutionary socialist considered as one of the fathers of the ultra-left in France. The quote implies that one can meet basic needs and have a decent life (represented by the bread), only through fighting (the iron metonymically referring to weapons). This quote not only anchors the mobilization in extreme-left ideologies but also displays knowledge and appropriation of France's political history. 'On pense donc on ne vous suit plus' is written in large capital spray paint letters over a torn poster that advertises the Louvre/Nanterre street art project. This pun on Descartes's cogito ergo sum 'je pense donc je suis' ('I think therefore I am') rests on the homophony in French between 'je suis' ('I am') and 'on suit' 


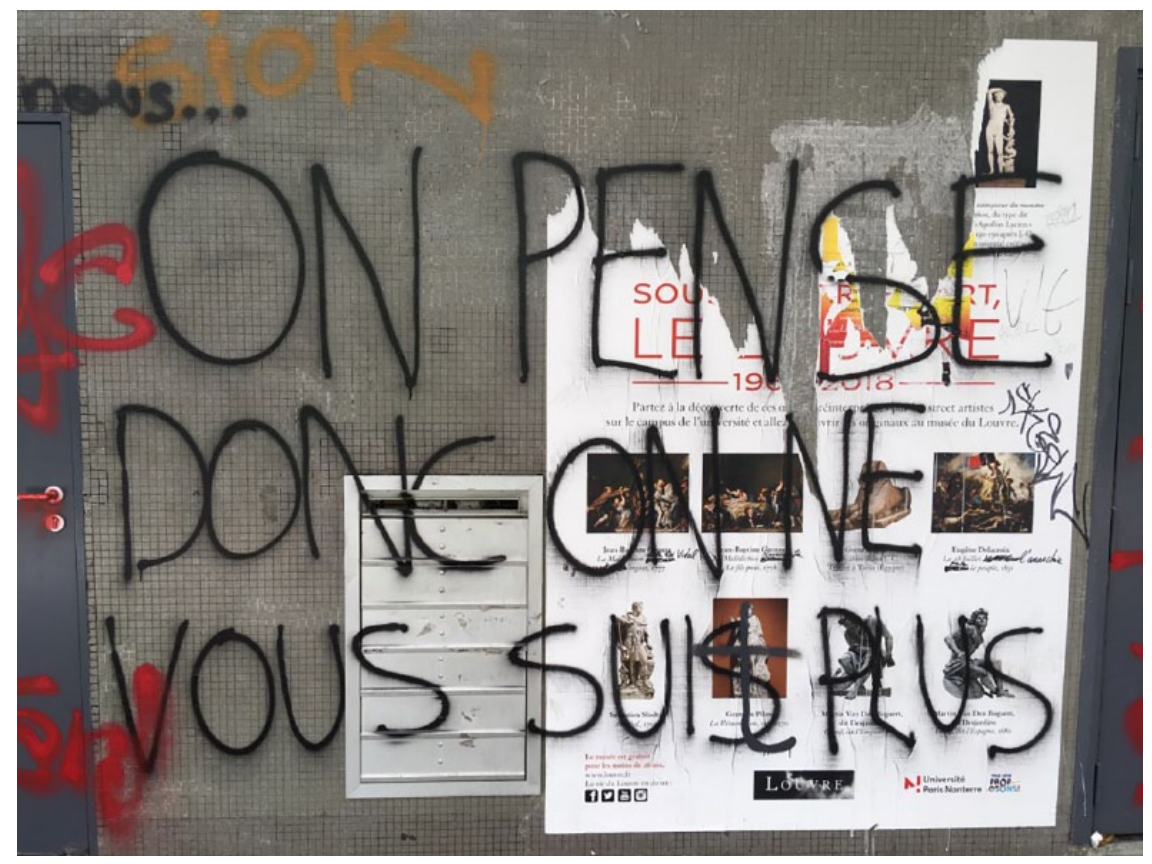

Figure 7. Torn Louvre/Nanterre street art project poster, graffiti, outside wall, building C.

('we follow'), in the negative form 'on ne vous suit plus' ('we won't follow you anymore'). This revised version of the cogito expressed an awakening to critical thinking, leading to breaking away from official institutionalized ideologies and discourses (a position also visible in the tearing and tagging of the poster).

\section{Spatial anchoring: indexicalities and converging fights}

Stating the movement's legitimacy was not done only in time but also in space. One major objective of the mobilized team was to make the movement grow; the graffiti thus served purposes of inviting new members to join the movement, stating how broad the movement was and how connected it was to other socio-political claims beyond the academic world. The graffiti were used to mark space at least temporarily so as to make the movement last in time. With graffiti, the movement was anchored in different relevant spaces, at different scales, from the local to the international. Local anchoring was expressed by reference to suburban culture, with specific anchoring in the 'Hauts-de-Seine' department, written 'Haut-2-Seine' based on the homophony between 'de' ('of') and '2' ('deux') in French, on the main wall visible from the esplanade at the main entrance of the campus. This spelling anchored the movement in youth culture with markers like approximate and shortened spelling, as found in rap culture, on social networks and in SMS writing. (Sub)urban rap culture was constantly present in the graffiti, with reference to rap music artists, for example, 'Arkana avait 


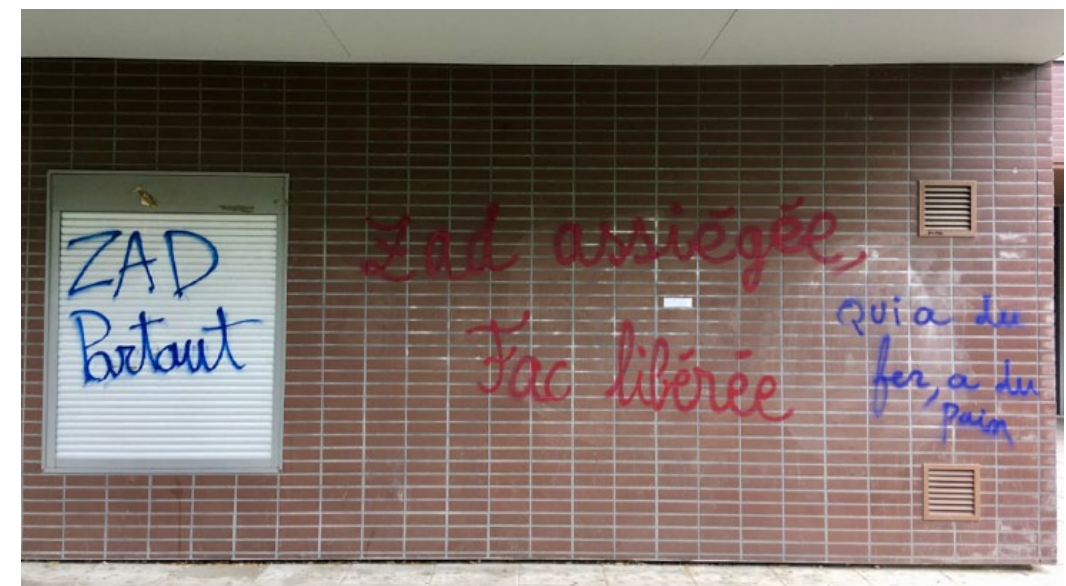

Figure 8. Graffiti, outside wall, Maison de l'Étudiant.

raison' ('Arkana was right', probably referring to female rap singer Keny Arkana) written on the main wall of Humanities building $\mathrm{L}$ and to their song lyrics, found mostly inside occupied building E. 'J'VOIS LA VIE EN ROUGE CAR LES FLAQUES DE SANG SONT RAREMENT ROSES' ('I see life in red because pools of blood are rarely pink') at the bottom of a staircase in building E. This quote by Parisian rap singer Jazzy Bazz alluded to the song line 'je vois la vie en rose' ('I see life in pink') from Edith Piaf's famous 1945 song 'La vie en rose', but in a much darker, more violent reinterpretation, mirrored by the dark locus of the graffiti on a wall below a flight of stairs. 'On sauvera pas toute la terre j'prends la couronne la pose sur la tête du petit frère' ('we won't manage to save the whole planet I take the crown and put it on the little brother's head') is a quote from a song by PNL ('Peace N'Lovés'), a famous rap music band from the northern suburbs of Paris.

Suburban rap culture was also marked by the vocabulary used: 'C'est à Nanterre qu'on tient le ter ter; Bondu, Raynaud, Bréchet on les enterter' ('It's in Nanterre that we keep our territory; we bury Bondu, Raynaud, Bréchet' ${ }^{37}$ ). 'Ter ter' is a suburban slang term meaning 'quarters', 'territory', obtained from clipping the word 'territoire' ('territory') and reduplicating the obtained syllable 'ter' to express affective closeness. 'on les enterter' is a pun on 'on les enterre' ('we bury them') where the verb is merged with 'ter ter' to create rhythmic repetition, both reminiscent of chanted political slogans and rap songs. 'Ter ter' expressed appropriation of the campus site in analogy with how suburban sectors are appropriated and denominated in rap culture and carries gang culture imagery.

The graffiti also referenced marking events in the history of police violence in the larger Paris area, as in 'igo jsuis pas Charlie, jsuis Adama, jsuis Malik Oussekine' ('igo I'm not Charlie, I'm Adama, I'm Malik Oussekine'), in a corridor of the first floor in building E. 'Igo' is a term of suburban slang meaning 'friend, brother' and a borrowing from Soninke, a West African language from the Sahel region. 'Je suis Charlie' ('I am Charlie') is a slogan that was massively widespread online after the terrorist attacks 
against the satirical journal Charlie Hebdo in Paris in January 2015. This slogan is rejected ('I am not Charlie') in favour of solidarity with victims of police violence. 'Adama' refers to Adama Traoré, a young Black man who died in July 2016 in the larger Paris area after a violent police hearing. Malik Oussekine was a student of North African dissent who also died after a violent police hearing, following his participation in a mass student protest in Paris against university reforms, back in 1986.

The Nanterre Campus was also inscribed in a larger network of occupied universities in the Paris area, with explicit support to the Censier (Paris 3) and Tolbiac (Paris 1) occupations. Slogans like 'Commune Libre de Censier', 'Libérez Tolbiac', 'Commune libre de Tolbiac avec P10', ('Free Commune of Censier', 'Free Tolbiac', 'Free Commune of Tolbiac with P10', 'P10' alluding to 'Paris 10', which is Nanterre University's former name) frame university occupations as reiterations of the Paris Commune of 1871, that is, alternative, autonomous places free from political authority.

'ZAD' (acronym of 'Zone A Défendre', 'Zone to Defend') was also a very frequent graffiti. The graffiti 'ZAD assiégée, Fac libérée' ('besieged ZAD, free university', Figure 8) on an outside wall of the Maison de l'Etudiant expressed continuity of resistance to police repression, with the university mobilization taking up the fight while the anti-airport ZAD was being dismantled. On campus, solidarity with the Notre-Damedes-Landes ZAD was also expressed by multiple posters of large black-and-white pictures of masked activists fighting back the riot police. But ZAD also had a generic understanding in the graffiti, namely that of an alternative, politically autonomous space: 'ZAD partout' ('ZAD everywhere', Figure 8), 'NTR ZAD' ('NTR' stands up for Nanterre and was the alternative name of the university used by the mobilized group online) and in wishes for political autonomy to extend as in 'La France est une grosse ZAD' ('France is a big ZAD').

The frequent use of 'NTR' not only marked appropriation of the university as a site and as an institution through the use of an alternative name, it also created continuity between the mobilized presence on site and online. The continuity between the real and the digital mobilization was also expressed with the recurrent graffiti 'gneugneugneu X', with $\mathrm{X}$ being an item discredited by this structure. '\#gneugneugneu', a widespread hashtag on Twitter, is an informal onomatopoeic way of expressing disagreement and despise towards a person or statement as inaudible and uninteresting (an informal equivalent of 'nonsense'). It was used repeatedly in the graffiti, mostly inside building E: 'gneugneugneu VIDAL', 'gneugneugneu MACRON', 'gneugneugneu Balaudé', 'gneugneugneu le vandalisme', among others.

The centrifugal aim of the movement, meant to be relevant beyond local mobilization, was visible through the use of multiple languages. For instance, 'Nanterre sur les toits' was found multiple times in a Spanish word-to-word equivalent 'Nanterre sobre los techos' and the famous Italian anarchist slogan 'nervi tesi, fasci appesi' ('tense nerves, hanging fascists') ${ }^{38}$ was tagged in the main mobilization room on the ground floor in building E.

The mobilization and its revindications for French universities was also connected to a variety of other political claims. This form of multi-issuism is typical of university movements (Rolland-Diamond, 2016) and was explicitly rejected as inacceptable by the University's presidential team. ${ }^{39}$ Multi-issuism is highly connected to the trade union tradition in France and to May 68 in particular, in the form of 'convergence des luttes' 
('converging fights'), that is, the idea that the convergence of multiple sectors in a larger movement of social protest will produce more results. ${ }^{40}$

Especially inside building E, graffiti evoked a variety of political claims: 'PKK' expressed support to the Kurdistan's workers' party through its acronym; 'Palestine vivra, Palestine vaincra' ('Palestine will live, Palestine will overcome') expressed support to Palestine against Israel. The renaming of amphitheatre E2 as Amphi Martha P Johnson after the eponymous Black transgender activist is connected with several other expressions of transgender and LGBT activism: 'cis-mecs à la poubelle' ('cis-men in the trashbin' $)^{41}$ rejects heterosexual men as representatives of patriarchy; 'à bas la binarité' ('down with binarity') rejects the dichotomous distinction between men and women as simplistic; 'mon genre n'existe pas et tant mieux' ('my gender doesn't exist and that's for the best'). Feminist issues are expressed through detailed posters giving detailed information and explanations on the notion of sexual consent. The intersection between sociopolitical claims often merges anarchist signs, which are combined with LGBT issues, as in the graffiti 'FLGBTZ ...' (Figure 2), which conflates 'FLGBT' meaning 'Fierté Lesbienne Gay Bisexuelle Transgenre' ('Lesbian Gay Bisexual Transgender Pride') and ZAD ('Zone à Défendre'). An alternative version of the anarchist A conflates the signs for male and female, associating it with transgender activism. The graffiti 'ARAB$\mathrm{ACAB}$ même combat' ('ARAB-ACAB same fight', Figure 6) equates the racism suffered by people of North African descent with anarchist fights.

In the communique following the riot police intervention of 9 April 2018, the University's presidential team discarded the variety of claims expressed by mobilized students as random and inconsistent. Yet, a close analysis of the graffiti suggests another interpretation: they actually do constitute a consistent, larger web of interconnected socio-political revindications, that unite in questioning and criticizing multiple facets of political realities experienced as institutionalized oppression.

\section{Concluding remarks}

During the national student mobilization in the spring of 2018, the campus of Nanterre University, whose premises were partially occupied night and day, was the locus of over 500 physical interventions, among which over 400 graffiti. Graffiti are, rightfully, considered as inacceptable degradations of public premises. But they also constitute a unique form of political discourse and testimony of social life, relevant both at a micro and macro level, which is not found elsewhere and which, for that reason, deserves detailed study.

The present article aimed to identify the main functions fulfilled by graffiti as political discourse. While each analytical section could lead to a detailed analysis of its own, this article was meant as an overview of the political issues at stake in Nanterre University's linguistic landscape during that period. The university's main entrance was remodelled to re-stage the founding traumatic event of the riot police intervention that triggered the mobilization and partial occupation of the premises (section 'Setting the scene: remodelling the university's main entrance'). The graffiti expressed freedom, in the form of resistance inspired from anarchist and autonomous movements, reclaiming the university's identity and manifesting presence on site (section 'Expressions of freedom: resist oppression, 
reclaim identity, manifest presence'). The graffiti had an interactional function: they were used to establish dialogue with local and national authorities (section 'Enable dialogue: mobilized groups talk (back) to authorities'). The graffiti also sought legitimization of the mobilization both in time and space, by anchoring the movement in a larger web of historical references and sites of political resistance (sections 'Stating legitimacy in time: historical and intellectual anchoring' and 'Spatial anchoring: indexicalities and converging fights'). Each analytical section could deserve a separate study of its own.

Over the summer of 2018, all the political graffiti linked with the mobilization were carefully cleaned, repainted and erased, while older tagging was left untouched: this selective makeover indicates that graffiti are not just physical degradation but also political discourse and action. A striking feature of the political graffiti on the campus of Nanterre University is their complex indexicality. Each discourse item is relevant at multiple scales, by addressing issues, times, places and people beyond the here and now of the physical intervention, in various forms such as quotes, direct address, references and symbols. It is precisely this multilevel indexicality that anchors graffiti and their authors in larger historical, geographic, social, historical and intellectual networks of relations, thereby endowing graffiti with political power.

\section{Acknowledgements}

The author would like to thank Cécile Viollain, Véronique Rauline, Alexia Stergiopoulos and Naïra Melikian for their suggestions, input and advice on this article.

\section{Declaration of conflicting interests}

The author(s) declared no potential conflicts of interest with respect to the research, authorship, and/or publication of this article.

\section{Funding}

The author(s) declared no potential conflicts of interest with respect to the research, authorship and/or publication of this article.

\section{Notes}

1. https://en.wikipedia.org/wiki/Daniel_Cohn-Bendit. All webpage references for the article were consulted on 7 September 2018.

2. https://prop-osons.parisnanterre.fr/.

3. http://congres2018.saesfrance.org/

4. https://www.parisnanterre.fr/actualites/le-street-art-s-installe-a-l-universite-812994.kjsp

5. See: https://www.nanterre.fr/2240-mai-68-ici-et-encore.htm for an overview of events organized for the 50th anniversary of May 68 by the Nanterre city council.

6. A description of Parcoursup/ORE can be found on the French Ministry for Higher Education, Research and Innovation's website: http://www.enseignementsup-recherche.gouv.fr/pid37384/ parcoursup-la-plateforme-d-admission-dans-l-enseignement-superieur.html.

7. This vision is for instance expressed in a tribune signed by more than 900 faculty members, published on 25 May 2018 in the daily paper Libération, originally written by Law Professors from Paris Nanterre University. http://www.liberation.fr/debats/2018/05/25/ parcoursup-1-imposture_1654089.

8. https://zad.nadir.org/ is the website of the defenders of the ZAD at Notre Dame des Landes. 
9. See, for instance, the account of the riot police interventions by daily paper Libération dated 9 April 2018, the day of the riot police intervention at Nanterre University: http://www.liberation.fr/france/2018/04/09/notre-dame-des-landes-debut-des-expulsions-affrontements-entregendarmes-et-zadistes_1642040.

10. See, for instance, http://www.europe1.fr/economie/sncf-le-calendrier-de-la-greve-jusquaujeudi-28-juin-3634367

11. The archive of the mobilized personnel and faculty's mailing list 'personnels en lutte' is accessible online: https://framalistes.org/sympa/arc/personnelsenluttenanterre/2018-09/

12. https://www.facebook.com/pages/category/Nonprofit-Organization/ Etats-g\%C3\%A9n\%C3\%A9raux-\%C3\%A0-Paris-Nanterre-174681946572874/

13. http://www.leparisien.fr/hauts-de-seine-92/fac-de-nanterre-1600-etudiants-en-assembleegenerale-17-04-2018-7668648.php

14. https://www.lemonde.fr/campus/article/2018/05/11/reforme-des-universites-tensions-lorsdu-blocage-d-examens-delocalises-a-arcueil_5297426_4401467.html

15. The list of official communiqués by the Presidential team is accessible online: https:// www.parisnanterre.fr/actualites/flash-info-journees-des-9-avril-au-14-juin-2018-836690. kjsp?RH=univ

16. For instance on the occasion of a radio interview on 18 April 2018 at the morning show of France Inter, which has the largest audience in France: https://www.franceinter.fr/emissions/1invite-de-8h20-le-grand-entretien/l-invite-de-8h20-le-grand-entretien-18-avril-2018

17. http://www.leparisien.fr/societe/mai-68-printemps-2018-meme-combat-memes-slogans-05-04-2018-7648200.php

18. See, for instance, https://www.franceinter.fr/societe/a-nanterre-les-profs-votent-un-20-20politique

19. Macron gave this interview on TV channel TF1 on 12 April 2018: https://www.marianne.net/ politique/il-n-y-aura-pas-d-examen-en-chocolat-lance-macron-aux-etudiants-grevistes-sur-tf1

20. https://twitter.com/ntr_vnr?lang=fr

21. The mobilized students' Facebook account is 'Nanterre Vénère en lutte contre la sélection et le Plan Étudiant' ('Angry Nanterre fighting selection and the university reform'): https:// www.facebook.com/NTR.VS.VIDAL/?fb_dtsg_ag=Ady91oRVgS9dwMn5vLlp68Gw6uF5 Zpk988Yu58WOJlwpvQ\%3AAdz0tTJJCQsq98DtTH2yAk6qPlvsbKW7KoWd7Y1Ldqq sow

22. See, for instance, a communiqué dated 21 April 2018 reposted on the SNESUP website, a union for higher education workers: http://www.snesup.fr/article/universitede-nanterre-abrogation-de-la-loi-ore-les-personnels-renouvellent-leur-opposition

23. https://en.wikipedia.org/wiki/Liberty_Leading_the_People

24. TV interview given on CNews on 17 April 2018: https://www.huffingtonpost.fr/2018/04/17/ tolbiac-violence-drogue-sexe-le-president-de-la-fac-denonce-une-situation-preinsurrectionn elle_a_23412977/

25. https://www.facebook.com/Paris 1 Deter/videos/1809311072703821/?hc ref=ARQ8mt70tsh3g5LVTg8x-Wgqmguq_Gku0pyvyD5skmrzk_327cQ-x4Rdjr8HbmziYlk

26. https://www.lemonde.fr/campus/article/2018/04/25/cinq-jours-apres-l-evacuation-de-tolbiac-la-verite-se-fait-jour_5290256_4401467.html

27. https://www.parisnanterre.fr/l-universite/communique-du-president-de-l-universite-apresles-evenements-de-ces-derniers-jours-837264.kjsp

28. https://en.wikipedia.org/wiki/Omar_Raddad_Affair

29. A 2005 fantasy musical film by Tim Burton starring Johnny Depp and adaptation of Roald Dahl's 1964 eponymous children's novel.

30. In the late 1960 s, many streets in Paris were still made of cobblestone, which rested on a layer of sand. Protesters used cobbles as projectiles against the riot police and had come 
up with this slogan evoking freedom, carelessness and leisure conveyed by the positive image of the beach which alluded to the sand, inciting people to take out the cobbles from the streets.

31. 'malox' is a misspelt reference to Maalox, a brand of stomach-burn medicine used by protesters to relieve skin irritations caused by teargas.

32. 'My love has got no money, he's got his strong beliefs / My love has got no power, he's got his strong beliefs / Want more and more / People just want more and more / Freedom and love, what he's looking for / Freed from desire, mind and senses purified'.

33. See, for instance, https://bangaloremirror.indiatimes.com/opinion/views/the-politics-ofrenaming/articleshow/59098847.cms on the politics of renaming universities.

34. In the article, I use the old naming system, referring to buildings by letters. The list of new names is accessible online: https://www.parisnanterre.fr/presentation/memoires-des-lieuxnouvelle-signaletique-exterieure-799596.kjsp

35. Martha P Johnson was an American transgender drag queen and lesbian, gay, bisexual and transgender (LGBT) activist who was a famous figure of the Stonewall uprising, a series of spontaneous, violent demonstrations by members of the LGBT community against a police raid that took place in June 1969 at the Stonewall Inn in Manhattan, New York City. The Stonewall uprising is considered to constitute a founding event for the gay liberation movement and the modern fight for LGBT rights in the United States.

36. https://en.wikipedia.org/wiki/Angelus_Novus provides the English version of this text: 'A Klee painting named Angelus Novus shows an angel looking as though he is about to move away from something he is fixedly contemplating. His eyes are staring, his mouth is open, his wings are spread. This is how one pictures the angel of history. His face is turned toward the past. Where we perceive a chain of events, he sees one single catastrophe which keeps piling wreckage upon wreckage and hurls it in front of his feet. The angel would like to stay, awaken the dead, and make whole what has been smashed. But a storm is blowing from Paradise; it has got caught in his wings with such violence that the angel can no longer close them. The storm irresistibly propels him into the future to which his back is turned, while the pile of debris before him grows skyward. This storm is what we call progress'.

37. Bondu, Raynaud and Bréchet are three persons who are part of the University's presidential team.

38. This anarchist slogan alludes to the hanging dead bodies of Mussolini and his acolytes in Milan in April 1945.

39. As stated in the communique that followed the riot police intervention, see https://www.parisnanterre.fr/l-universite/communique-du-president-de-l-universite-apres-les-evenements-deces-derniers-jours-837264.kjsp

40. The convergence of social protest worked notably at least twice in France, when massive workers' strikes led to social advances with the apparition of paid holidays in 1936 and higher wages in 1968. With the ZAD occupation, the national train company's strike and the occupation of universities, the convergence of grassroots movements seemed possible in the spring of 2018 , but did not, in fact, really happen.

41. In gender studies, cisgender is a term used to describe people whose gender identity matches the sex that they were assigned at birth.

\section{References}

Abel E and Buckley B (1977) The Handwriting on the Wall: Toward a Sociology and Psychology of Graffiti. Westport, CT: Greenwood.

Adams K L and Winter A (1997) Gang Graffiti as a discourse genre. Journal of Sociolinguistics 1(3): 337-360. 
Barni M and Bagna C (2009) A mapping technique and the linguistic landscape. In: Shohamy E and Gorter D (eds) Linguistic Landscape: Expanding the Scenery. New York: Routledge, pp. $126-140$.

Blume R (1985) Graffiti. In: Van Dijk T (ed.) Discourse and Literature. Amsterdam; Philadelphia, PA: John Benjamins, pp. 137-148.

Cole C (1991) Oh wise women of the stalls ... Discourse Society 2(4): 401-411.

Farnia M (2014) A thematic analysis of graffiti on the university classroom walls - A case of Iran. International Journal of Applied Linguistics \& English Literature 3(3): 48-57.

Green J (2003) The writing on the stall: Gender and graffiti. Journal of Language and Social Psychology 22(3): 282-296.

Hanauer D (1998) A genre approach to graffiti at the site of Prime Minister Rabin's assassination. In: Zissenzwein D and Schers D (eds) Present and Future: Jewish Culture, Identity and Language. Tel-Aviv: Tel-Aviv University Press, pp. 89-97.

Hanauer D (2004) Silence, voice and erasure: psychological embodiment in graffiti at the site of Prime Minister Rabin's assassination. The Arts in Psychotherapy 31: 29-35.

Hanauer D (2011) The discursive construction of the separation wall at Abu Dis: Graffiti as political discourse. Journal of Language and Politics 10(3): 301-321.

Kostka R (1974) Aspects of graffiti. Visible Language 8: 369-375.

Matthews N, Speers L and Ball J (2012) Bathroom banter: Sex, love, and the bathroom wall. Electronic Journal of Human Sexuality 15(17): 1-11.

Nwoye O (1993) Social issues on walls: Graffiti in university lavatories. Discourse \& Society 4: $419-442$.

Obeng S (2000) Speaking the unspeakable: Discursive strategies to express language attitudes in Legon (Ghana) graffiti. Research on Language and Social Interaction 33(3): 291-319.

Otta E (1993) Graffiti in the 1990s: A study of inscriptions on restroom walls. Journal of Social Psychology 133: 589-590.

Peteet J (1996) The writing on the walls: The graffiti of the intifada. Cultural Anthropology 11(2): $139-159$.

Pietrosanti S (2010) Behind the Tag: A Journey with the Graffiti Writers of European Walls. Amsterdam: University of Amsterdam.

Rolland-Diamond C (2016) Black America. Une histoire des luttes pour l'égalité et la justice (XIXe-XXIe siècle) [Black America. A history of struggles for equality and justice (19th-21st C.)]. Paris: La Découverte.

Schreer G and Strichartz J (1997) Private restroom graffiti: An analysis of controversial social issues on two college campuses. Psychological Reports 81: 1067-1074.

Show F, Copland S and Snell J (eds) (2015) Linguistic Ethnography: Interdisciplinary Explorations. Basingstoke; New York: Palgrave Macmillan.

Tanzer H (1939) The Common People of Pompeii: A Study of the Graffiti. Baltimore, MD: The John Hopkins Press.

Wodak R (2006) 'Doing politics': The discursive construction of politics. Journal of Language and Politics 5(3): 299-303.

\section{Author biography}

Camille Debras is a Lecturer (Maître de Conférences) in English Linguistics at Université Paris Nanterre, France. The main focus of her research is on the multimodality of discourse in interaction. She studies how speakers integrate speech and gesture to construct meaning intersubjectively, in various contexts such as adult interaction, native-learner interaction or political address. Her research interests include interactional linguistics, linguistic anthropology, discourse analysis, nonverbal communication and multimodal semiotics. 